\title{
FIELD ASSESSMENT OF PERFORMANCE WATER LOSSES OF CENTER PIVOT IRRIGATION SYSTEMS UNDER ARID CLIMATE CONDITIONS
}

\author{
MOHAMED S. A. EL MARAZKY ${ }^{1,2}$
}

1. Agriculture Engineering Research Institute, ARC, (AEnRI), P. O. Box 256, Cairo, Dokki - Giza - Egypt.

2. Departments of Agricultural Engineering, College of Food and Agriculture Sciences, King Saud University, Riyadh 11451, Saudi Arabia.

(Manuscript received 26 July 2016 )

\begin{abstract}
$\mathrm{T}$ he center pivot system is the one of the most appropriate sprinkler systems for arid or semi-arid areas where a great deal of irrigating water. The system is used widely in Saudi Arabia, and there were more than 20,000 center pivot systems in the country. To know the reality of water application, water losses and distribution uniformity by this type of irrigation system in this country, a study was conducted in Riyadh region to evaluate 8 centers pivot systems with different ages and made of various companies and consisted of different number of towers ranged from 4 to 10 . The results showed that most of the center pivot systems gave low distribution uniformity during water application at the irrigated areas. The values of coefficient of uniformity $(\mathrm{Cu})$ were ranged between $69.2 \%$ and $89.2 \%$, while the values of distribution of uniformity of low quarter (Du) were between $54.1 \%$ and $81.6 \%$, and water losses from these systems were ranged between $7.83 \%$ and $13.57 \%$. The study also investigated the effect of main factors on water distribution and water losses in arid areas by developing a statistical model in order to determine relationship between the losses and the factors affecting them under operating field conditions. The results of this study could assist the farmers to identify the irrigation and how to improve the system performance and the developed regression model could provide valuable information for the water application and water losses with center pivot irrigation system in region facing aridity and water scarcity.
\end{abstract}

Keywords: Hydraulic parameter, application uniformity, sprinklers, mathematical model, field evaluation.

\section{INTRODUCTION}

Irrigation is an increasingly important practice for sustainable agriculture in the arid and semiarid regions of the world. Water is the most important resource and limiting factor for agricultural development in the arid regions in general and in Saudi Arabia in particular. One of the important agricultural limitations, in Saudi Arabia, is the shortage of suitable water sources besides balancing supply and demand while, facing aridity and water scarcity (Mohorjy and Grigg, 1995). For an attainment of 
sustainable water use, the resources have to be utilized in such a manner as to protect and conserve the available water reserves (Sezen and Yazar, 2006).

Center pivot irrigation (CP) systems are among the most popular for irrigating field crops and are used on over half of sprinkler irrigated lands in many countries (Allen et al., 2000). CP has experienced worldwide success because of their advantages relative to other irrigation systems. Such advantages typically include, high potential for uniform and efficient water application; high degree of automation; and ability to apply water and nutrients over a wide range of soil, crop and topographic conditions (Evans and King, 2012). CP comprises approximately two thirds of all the irrigation systems, in about $75 \%$ of the total irrigated areas in the Kingdom of Saudi Arabia (Al-Ghobari, 2014). The number of CP sprinkler irrigation systems has increased rapidly in the Kingdom of Saudi Arabia (KSA), as automatic and modern irrigation systems. In fact, in 1992 there were about 20,0 * center pivots in the country, which mainly imported to irrigate wheat and forage crops (Al-Ghobari and Mohammed, 1995). These sprinkler irrigation systems have allowed agricultural development of "marginal" lands unsuitable for surface irrigation in many areas across the KSA, mostly suffering from light sandy soils of large variations in topography within the same field.

$\mathrm{CP}$ systems generally entail a larger upfront investment but require less labor to operate and have a lower water application cost than a solid set system (Ortiz et al., 2010) and therefore it is the most commonly used sprinkler irrigation system in plots greater than 10-15 hectare (ha) when there is no restriction on factors such as shape, layout, and size of the field. In irrigated agriculture, this will have to be achieved through effective management of water use. Therefore, CP will have to handle and use water in their most efficient ways possible to prevent unnecessary losses (Dukes and Perry, 2006). Proper irrigation uniformity in center pivot systems is important since it has both economic and environmental implications. Harrison and Perry (2007) classified pivot coefficient uniformity (CU) values as excellent: >90\%, good: 85 to $90 \%$, fair: 80 to $85 \%$, and poor: $<80 \%$. To achieve this, the uniformity coefficient with which the irrigation systems apply water will have to be high. The uniformity coefficient of a sprinkler irrigation system directly affects the system's application efficiency and crop yield (Dechmi et al., 2003). Poor distribution uniformity reduces yields due to water stress. It also increases financial and environmental costs (Clemmens and Solomon, 1997).

The uniformity of water application could be influenced by many factors, some of the main ones being improper sprinkler nozzles and spacing, wear of sprinklers and pipes, variation in pressure distribution along the lateral as well as climatic 
parameters, such as wind speed and air temperature (Al-Ghobari, 1992, 1996). Field evaluation is an excellent procedure for determining the actual water distribution at field level. Several articles have been published describing application efficiency and distribution water uniformity as well as water losses from field evaluations of sprinkler irrigation systems (Kincaid, 1986; Tarjuelo et al., 1999). These articles present additional data to know the influence of main factors on water distribution in arid areas. Considerable research by many investigators has been conducted in the field to evaluate the performance of the center pivot sprinkler irrigation systems (Clemmens and Solomon, 1997; Tarjuelo et al., 1999; Ring and Heerman; 2001; Rogers et al., 2009; Acar et al., 2010; Al-Ghobari, 2014; Mun et al., 2015). The objectives of this study were to evaluate the uniformity of water application of various CP systems under desert conditions of Riyadh region. As well as, to estimate and quantify the effect of the main factors influencing water losses during irrigation.

\section{MATERIALS AND METHODS}

Eight low-pressure center pivot sprinkler irrigation systems operated at fields located in different areas of Riyadh region in the central of Saudi Arabia were evaluated. The distribution of water application depths recorded from spray nozzles along the lateral was assessed. The region is classified as hot and dry with desert climate, and the average annual rainfall and evaporation were about $50 \mathrm{~mm}$ and 4500 $\mathrm{mm}$ respectively (Hasanean and Almazroui, 2015). The irrigation system used in each field was center pivot sprinkler system and each system irrigates area ranged between 25 to 60 hectares. Hydraulics specifications of the center pivot system laterals employed in this study are shown in Table (1).

\section{Water application uniformity}

Irrigation uniformity can often be characterized by a coefficient which is calculated on the bases of water collected in catch cans or on the bases of changes in soil water content at a discrete measurement point in the field. As pointed out by Dechmi et al. (2003), irrigation uniformity was the most valuable outcome of the evaluation process in sprinkler irrigation. Several formulas were designed to describe the uniformity of the sprinklers water distribution and to evaluate their performance. The modified Heermann and Hein (1968) coefficient of uniformity $\mathrm{Cu}$ under center pivot system was used as follows: 
$C U=100\left|1-\frac{\sum_{i=1}^{n} r_{i}\left[D_{i}-\frac{\sum_{i=1}^{n} D_{i} r_{i}}{\sum_{i=1}^{n} D_{i} r_{i}}\right]}{\sum_{i=1}^{n} D_{i} r_{i}}\right|$

$\mathrm{Cu}=$ Heermann and Hein uniformity coefficient.

$\mathrm{Di}=$ total depth of application at distance $r_{i}$ from the pivot point.

$r_{i}=$ radial from the pivot point to the collector.

$\mathrm{i}=$ subscript denoting a point at a distance $\mathrm{Si} i=1---\rightarrow n$

$\mathrm{n}=$ number of catch cans.

Also, there is another index used to assess the uniformity of applied water in the irrigated area. This is the distribution uniformity $(\mathrm{Du})$ in the low quarter of center pivot irrigation system, which is given in Equ. (2) as follows:

$$
\mathrm{Du}=\frac{\mathrm{d}_{\mathrm{w}}}{\mathrm{D}_{\mathrm{w}}} \times 100 \quad(\text { ASABE, 2007). }
$$

Where $d_{w}$ is average of caught low quarter depth ( $\left.\mathrm{mm}\right)$ and $D_{w}$ is average of total caught depth applied. 
Table 1. Hydraulics specifications of center pivot system laterals employed under the studied area.

\begin{tabular}{|c|c|c|c|c|c|c|c|c|}
\hline \multirow{2}{*}{ Items } & \multicolumn{8}{|c|}{ No. of center pivots } \\
\hline & $\mathrm{CP} 1$ & $\mathrm{CP} 2$ & $\mathrm{CP} 3$ & $\mathrm{CP} 4$ & CP5 & CP6 & CP7 & CP8 \\
\hline Overall length, m & 305 & 395 & 265 & 405 & 345 & 375 & 315 & 390 \\
\hline Pipe diameter, inch & 5" & $65 / 8 "$ & $5 "$ & $65 / 8^{\prime \prime}$ & $65 / 8^{\prime \prime}$ & $65 / 8^{\prime \prime}$ & $6 "$ & 5" \\
\hline Nozzle type & $\begin{array}{l}\text { Nelson R3000 } \\
\text { Rotator -3TN }\end{array}$ & $\begin{array}{l}\text { Senninger } \\
(360 / c v-m)\end{array}$ & $\begin{array}{l}\text { Valley Low-Energy } \\
\text { Nozzle (LEN) }\end{array}$ & $\begin{array}{l}\text { Senninger } \\
(360 / c v-m)\end{array}$ & $\begin{array}{l}\text { Senninger } \\
(360 / c v-m)\end{array}$ & $\begin{array}{l}\text { Senninger } \\
(360 / c v-m)\end{array}$ & $\begin{array}{l}\text { Valley Low-Energy } \\
\text { Nozzle (LEN) }\end{array}$ & $\begin{array}{c}\text { Valley Low-Energy } \\
\text { Nozzle (LEN) }\end{array}$ \\
\hline Nozzle spacing, m & 2.01 & 2.01 & 2.50 & 2.01 & 2.03 & 2.03 & 2.03 & 2.00 \\
\hline $\begin{array}{c}\text { Pressure regulator } \\
\text { mode, Psi }\end{array}$ & 8.33 & 11.39 & 8.36 & 12.39 & 9.42 & 16.86 & 28.80 & 19.11 \\
\hline $\begin{array}{l}\text { Number of } \\
\text { sprinklers }\end{array}$ & 152 & 197 & 106 & 201 & 170 & 185 & 155 & 195 \\
\hline
\end{tabular}




\section{Water losses during irrigation ( $\left.\mathbf{W}_{\text {losses }}\right)$}

To illustrate how much amount of water was lost by evaporation, wind drift and leakage ( $\mathrm{W}_{\text {losses }}$ ) during the irrigation from CP system that have been evaluated in the field, $\mathrm{W}$ losses for each system has been determined by the following equation:

$$
\mathrm{W}_{\text {losses }}=\left(\frac{\mathrm{D}_{\mathrm{g}}-\mathrm{D}_{\mathrm{W}}}{\mathrm{D}_{\mathrm{g}}}\right) \times 100 \quad(\mathrm{ASABE}, 2007) \text {. }
$$

Where $D_{g}$ is gross depth of water applied from the system ( $\left.\mathrm{mm}\right)$.

\section{Field evaluation}

Field evaluation of a number of CP systems was carried out during 2016. The age of operating systems ranged from 2 to 18 years, and the number of towers varied from 6 to 9. All farms included in the evaluation belonged either to farmers or to agricultural companies.

The procedure of field evaluations were conducted adopting the methodology of Merriam and Keller (1978) and ASABE (2007). Climatic and center pivot parameters were measured and determined as shown in Table (2). The discharge rate of each center pivot system was measured using ultrasonic flow meter installed at the pivot pipe. Two rows of catch cans were used in each evaluation.

Table 2. Meteorological data and center pivot systems parameters.

\begin{tabular}{|c|c|c|c|c|c|c|c|c|}
\hline $\begin{array}{c}\text { Center } \\
\text { pivot } \\
\text { No. }\end{array}$ & $\begin{array}{l}\text { Wind } \\
\text { speed } \\
(\mathrm{m} / \mathrm{s})\end{array}$ & $\begin{array}{c}\text { Relative } \\
\text { humidity } \\
(\%)\end{array}$ & $\begin{array}{c}\text { Air } \\
\text { temperature } \\
\left({ }^{\circ} \mathrm{C}\right)\end{array}$ & $\begin{array}{c}\text { System } \\
\text { age } \\
\text { (year) }\end{array}$ & $\begin{array}{c}\text { Number } \\
\text { of } \\
\text { Towers }\end{array}$ & $\begin{array}{l}\text { Discharge } \\
\text { rate (L/s) }\end{array}$ & $\begin{array}{l}\text { Travel } \\
\text { speed } \\
\text { (m/min) }\end{array}$ & \begin{tabular}{|l} 
Area \\
rrigation \\
(ha)
\end{tabular} \\
\hline Cp1 & 2.68 & 19 & 22 & 15 & 6 & 47.19 & 1.7 & 29.22 \\
\hline Cp2 & 2.73 & 25 & 21 & 8 & 8 & 59.21 & 2.2 & 49.02 \\
\hline $\mathrm{CP} 3$ & 2.57 & 22 & 19 & 18 & 6 & 45.72 & 2.8 & 22.06 \\
\hline $\mathrm{CP} 4$ & 2.68 & 26 & 22 & 18 & 8 & 62.76 & 1.73 & 51.53 \\
\hline CP5 & 1.96 & 24 & 23 & 18 & 6 & 51.89 & 2.0 & 37.39 \\
\hline CP6 & 2.81 & 27 & 24 & 1 & 7 & 56.21 & 2.56 & 44.18 \\
\hline $\mathrm{CP7}$ & 2.93 & 23 & 26 & 10 & 6 & 48.64 & 1.17 & 31.17 \\
\hline CP8 & 2.96 & 28 & 25 & 5 & 9 & 60.34 & 2.53 & 47.78 \\
\hline
\end{tabular}

The uniformity of water distribution was measured in the radial direction along the lateral as shown in Fig. (1). The catch can spacing was chosen $5 \mathrm{~m}$ with the first can at $11.6 \mathrm{~m}$ from the pivot point. Catch cans of $16 \mathrm{~cm}$ inside diameters and 15 $\mathrm{cm}$ heights were used. The volume caught in each can was then converted to a depth in $\mathrm{mm}$ and plotted against the distance of each can position from the pivot point to 
give a visual display of the water caught in cans along the lateral line. The operating speed of the systems was set constant for all tested CP systems at $50 \%$. There was no end-gun sprinkler installed on any system tested. Field tests were carried out on either bare soil or soil with early staged crop growth. All tests were carried out under normal field conditions in the early morning to minimize the evaporation losses. The water collected in the catch cans was measured by graduated cylinders.

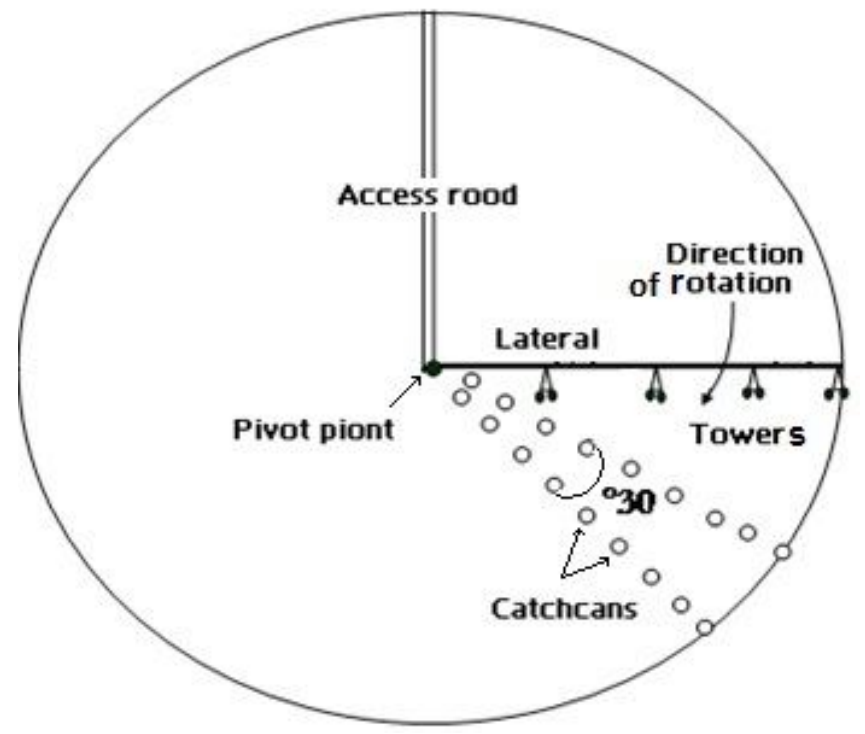

Fig. 1. Field layout and Schematic diagram representing distribution of catch cans.

\section{RESULTS AND DISCUSSION}

\section{Distribution of water depths along lateral}

Water distribution patterns along the laterals of the tested center pivot systems and the values of the average depths and the average of low quarter depths of water applied for each system were shown in Figs. ( 2 and 3). The patterns indicate that substantial areas of the center pivots especially No. 1 and 3 are receiving less than the average amount of water applied, and also it can be seen from the figure that there was a variation in depth of water applied along the lateral and from one system to another, and this variation was quite clear in the center pivot systems 1, 2, 3, 5 and 7. Most of these pivots gave coefficient of uniformity less than $85 \%$, which is the recommended minimum value for low pressure pivot irrigation systems.

Also, it could be observed from some patterns $(1,3,4$ and 8$)$ that there was a great depths at the beginning of the lateral (near the pivot) compared to the far end of the latera, whereas the opposite is true for some pattern of the center pivot systems ( 2 and 5 ). It could be due to the variation in the discharge of sprinklers 
adversely affected by the system age. Also, water leakage from the system was observed and it may be affecting the performance of the sprayers and the consequently affecting the water distribution pattern of the system. So, in general this non-uniformity might be attributed to meteorological factors, and center pivot system parameters, such as, wind speed, air temperature, improper nozzles, system age and pressure variation along the lateral.
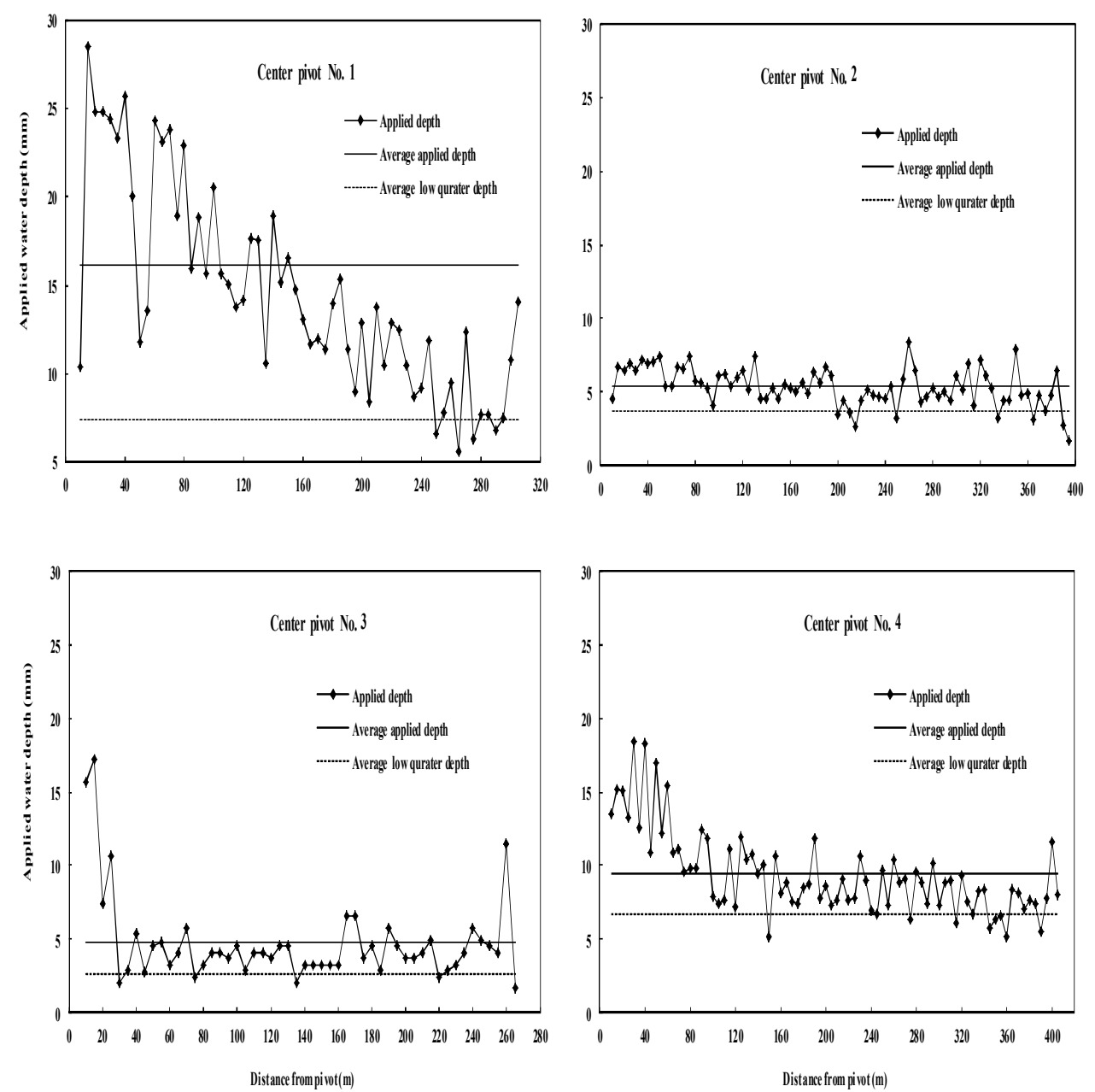

Fig. 2. Water distribution patterns in radial direction with the average depth and the average low quarter depth of application for different center pivot systems. 

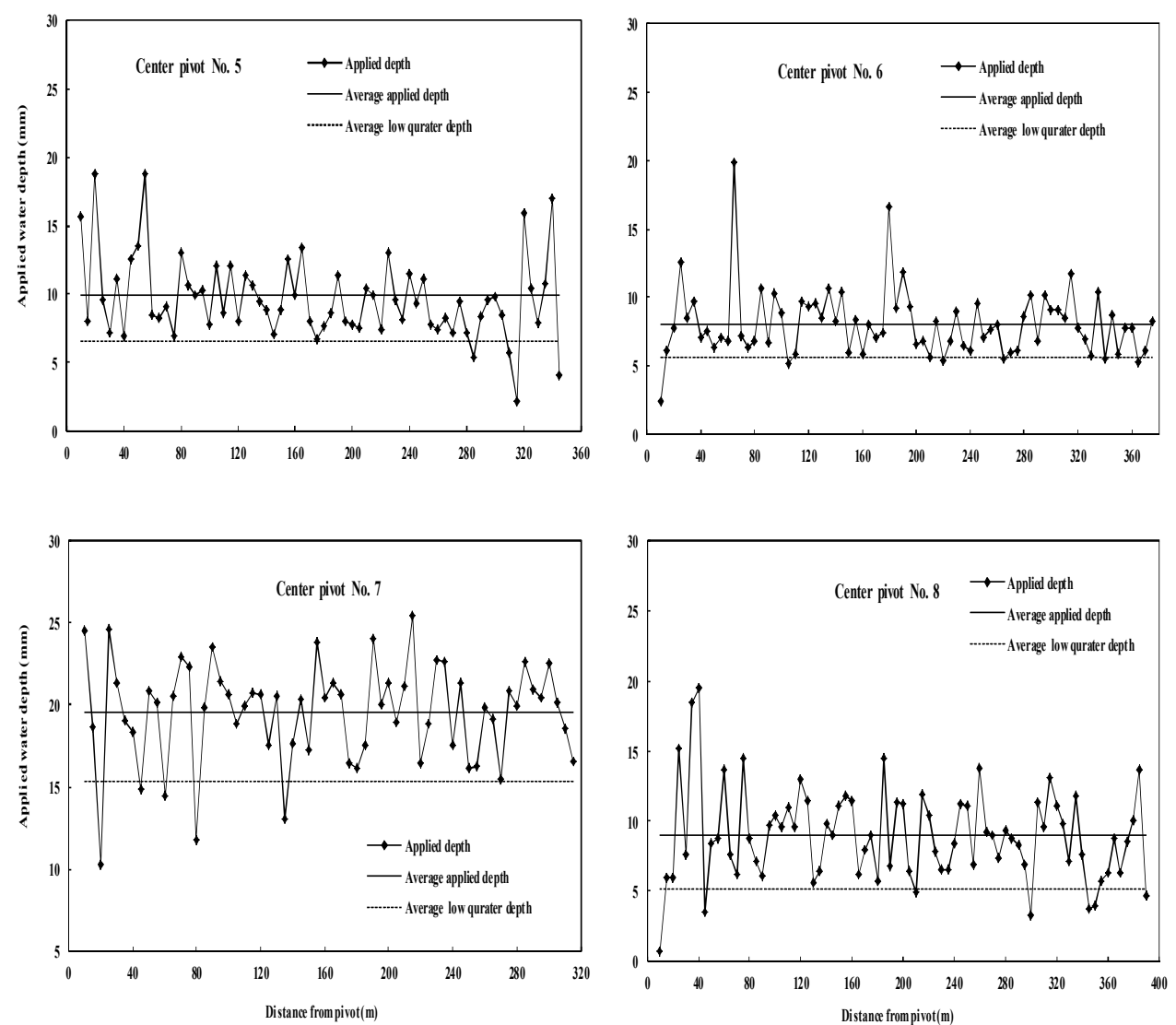

Fig. 3. Water distribution patterns in radial direction with the average depth and the average low quarter depth of application for different center pivot systems.

\section{Uniformity of water application}

Fig. (4) indicates the values of water distributions uniformity coefficient namely $\mathrm{Cu}$ and Du values. The average values of $\mathrm{Cu}$ were ranged between $69.2 \%$ and $89.20 \%$, with an average of $79.20 \%$. The highest and lowest values of $\mathrm{Cu}$ were $89.20 \%$ and $69.20 \%$ for CP systems No.7 and 1, respectively. CP system No. 7 has given high Cu value, and this was due to the use of new spray nozzles (low drift spray nozzles - LDN) despite the age of this system, which was 15 years. These spray nozzles reduced the effect of on water distribution uniformity. Generally, it can be judged from Fig. (3) that most of the evaluated low pressure center pivots have low $\mathrm{Cu}$ values less than $80 \%$, and this means that the distribution of water was unacceptable. 


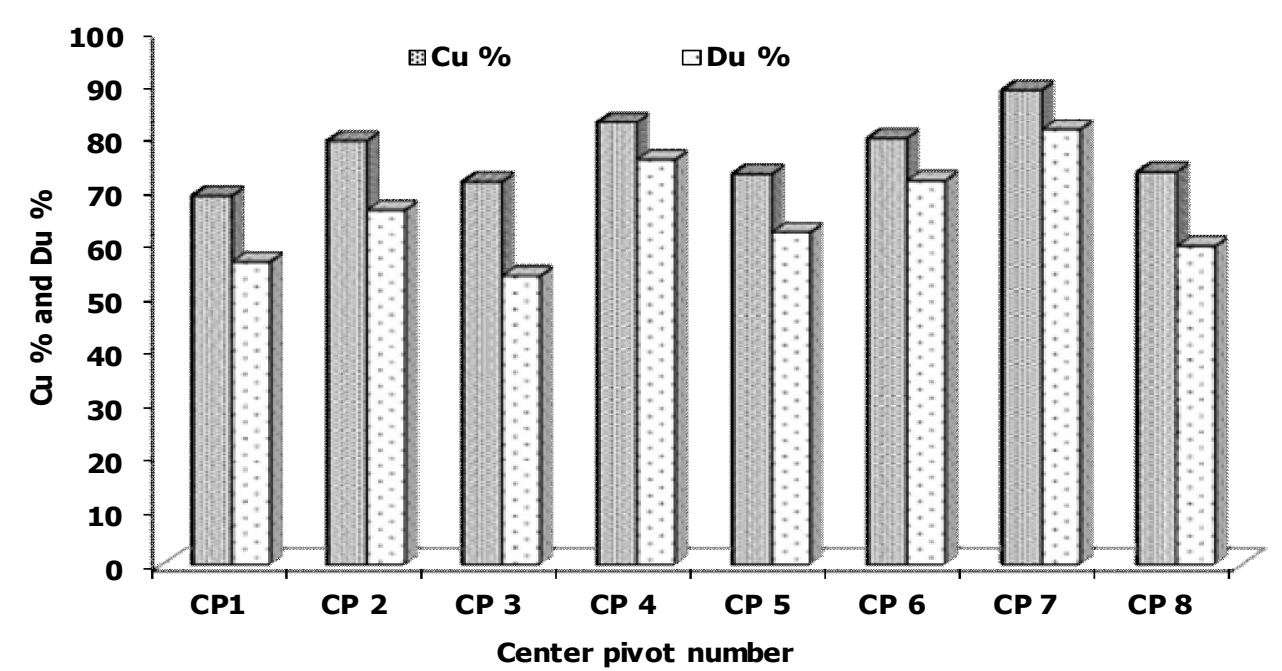

Fig. 4. Comparison between values of performance coefficients for various center pivot systems

\section{Calculations of water losses from center pivot systems}

Field study was carried out to determine the water losses from center pivot irrigation systems as a function of climatic data and irrigation system parameters. These parameters were the average wind speed, relative humidity, temperature, travel speed, age of the system and system discharge rates at different farms during field evaluations as shown in Table (2). Examination of these parameters shows that climatic parameters (wind speed, temperature, and relative humidity) were varied during the evaluation experiments.

The results obtained from the tested center pivot systems were utilized to develop an empirical regression model under hot and dry conditions to relate water losses as a function of the different climatic and irrigation system operational parameters. The multiple linear regression has the following form:

$W_{\text {losses }}=\beta_{0}+\beta_{1} \times X 1+\beta_{2} \times X 2+\beta_{3} \times X 3+\beta_{4} \times X 4+\beta_{5} \times X 5+\beta_{6} \times X 6$

Where $\mathrm{W}$ losses (\%) is water losses due to evaporation, wind drift and leakage, during irrigation and it is the percentage of the total water applied by the irrigation system.; $\mathrm{X} 1$ to $\mathrm{X} 6$ are the independents parameters and $\beta_{0}$ to $\beta_{6}$ are regression coefficients. $\mathrm{X} 1$ (wind speed, Ws, $\mathrm{m} / \mathrm{s}$ ), $\mathrm{X} 2$ (relative humidity, $\mathrm{RH}, \%$ ), $\mathrm{X} 3$ (air temperature, $\mathrm{T},{ }^{\circ} \mathrm{C}$ ), $\mathrm{X} 4$ (age of system, Sg, year), X5 (travel speed, $\mathrm{S}, \mathrm{m} / \mathrm{min}$ ) and $\mathrm{X} 6$ (system discharge rate, Qs, L/s). Multiple linear regression analysis was carried out using Excel spreadsheets. The criteria of a better fit were addressed by coefficient of determination $\left(R^{2}\right)$ and the standard error of regression. However, higher $R^{2}$ and smaller standard error of regression are preferred. 
The regression of water losses on related variables (wind speed, Ws, $\mathrm{m} / \mathrm{s}$ ), (relative humidity, $\mathrm{RH}, \%$ ), (air temperature, $\mathrm{T},{ }^{\circ} \mathrm{C}$ ), (age of system, $\mathrm{Sg}$, year), (travel speed, $\mathrm{S}, \mathrm{m} / \mathrm{min}$ ) and (system discharge rate, $\mathrm{Qs}, \mathrm{L} / \mathrm{S}$ ) was performed and the created multiple linear regression model is given as:

$$
\begin{gathered}
\mathbf{W}_{\text {losses }}=-12.4731+0.1994 \mathbf{W}_{\mathbf{s}}-0.5640 \mathbf{R H}+0.3325 \mathbf{T}+0.0011 \mathbf{S g}+2.6152 \mathbf{S}+0.4252 \mathbf{Q} \mathbf{s} \\
\left(\mathrm{R}^{2}=0.8669 \quad \text { Standard Error }=1.79 \%\right)
\end{gathered}
$$

Due to $\mathrm{R}^{2}$ indicates the amount of total variability explained by the regression model, thus $86.69 \%$ of the total variation in the water losses can be explained by the linear relationship between wind speed, relative humidity, air temperature, age of system, travel speed, system discharge rate and water losses. The other $13.31 \%$ of the total variation in the water losses remains unexplained. The limits of application of the prediction model (Eq.5) are including wind speed in the range of 1.96 to $2.96 \mathrm{~m} / \mathrm{s}$, relative humidity in the range of 19 to $28 \%$, air temperature in the range of 19 to 26 ${ }^{\circ} \mathrm{C}$, age of system in the range of 1 to 18 year, travel speed in the range of 1.17 to $2.8 \mathrm{~m} / \mathrm{min}$ and system discharge rate in the range of 45.72 to $62.76 \mathrm{~L} / \mathrm{s}$.

As indicted in Eq. (5), increasing travel speed resulted in increasing water losses and decreasing relative humidity resulted in increasing water losses and this finding is consistent with the results obtained by Al-Ghobari (1996) who reported that the travel speed of pivot irrigation system increases the losses spraying with increasing rotational speed. As well as low relative humidity increases the evaporation of the droplets emitted from the nozzle spray. Moreover, as seen in Eq. (5), increasing wind speed resulted in increasing water losses also, the same trend was observed for air temperature, however, Ortiz et al. (2010) reported that wind speed and direction were the main factors that affect water distribution pattern in sprinkler irrigation. Meanwhile, the coefficient of the age of system was 0.0011 as shown in Eq. (5) and that means this variable is less important for calculation water losses. On the other hand, the coefficient of the system discharge rate was 0.4252 as shown in Eq. (5) and that means this variable is more important for calculation water losses in a center pivot system. Thus, evaporation (water) loss can be reduced by operating a center pivot system under low temperature, low wind speed and high relative humidity.

Fig. (5) shows a comparison between calculated and predicted water losses from center pivot systems in Riyadh region according to Eq. (5) for eight systems. Also, Fig. (6) shows relationship between calculated and predicted water losses from center pivot systems in Riyadh region. As seen in the Fig. (6), a good agreement was observed between calculated and predicted water losses. Therefore, the $\mathrm{W}_{\text {losses }}$ model is considered acceptable for the prediction of water loss under arid climate conditions and may lead to great improvements in field water management through its inclusion in center pivot irrigation systems. 


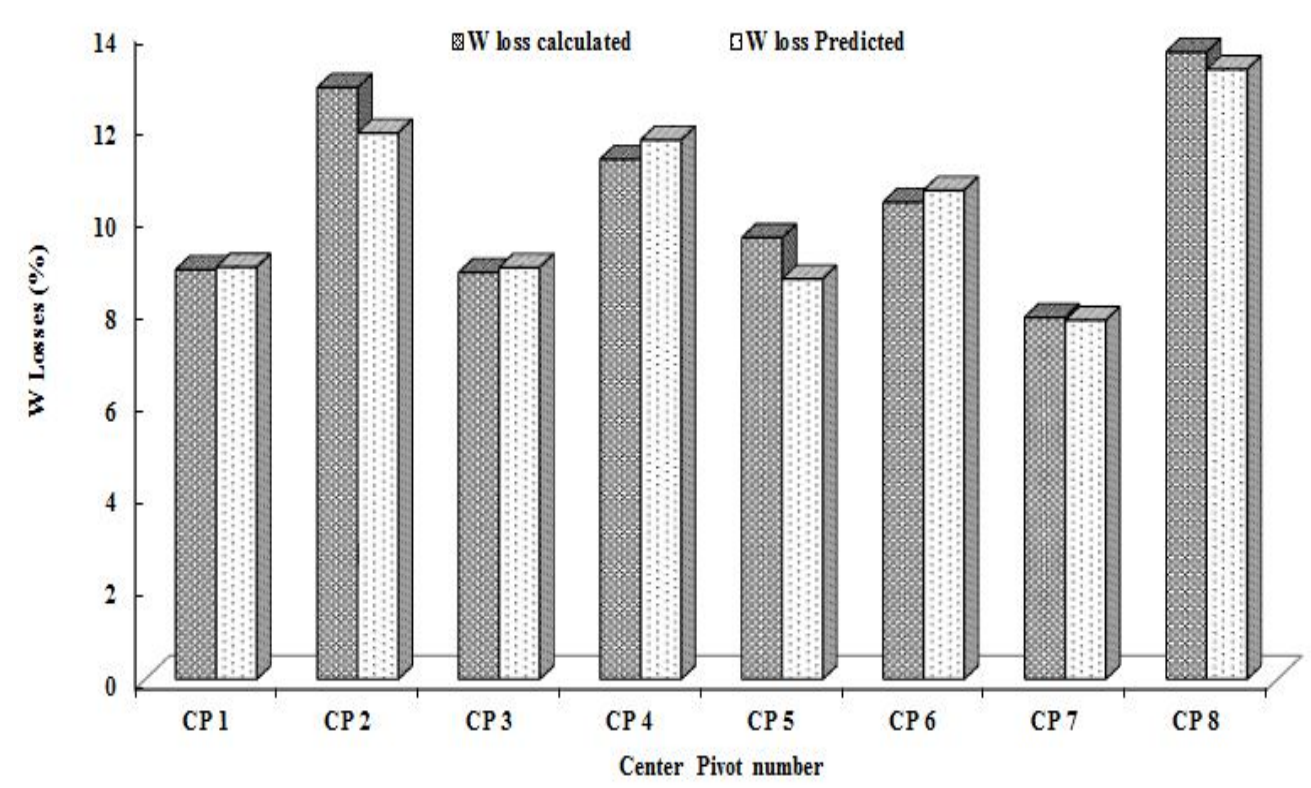

Fig. 5. Comparison of water losses for eight center pivot systems in Riyadh region.

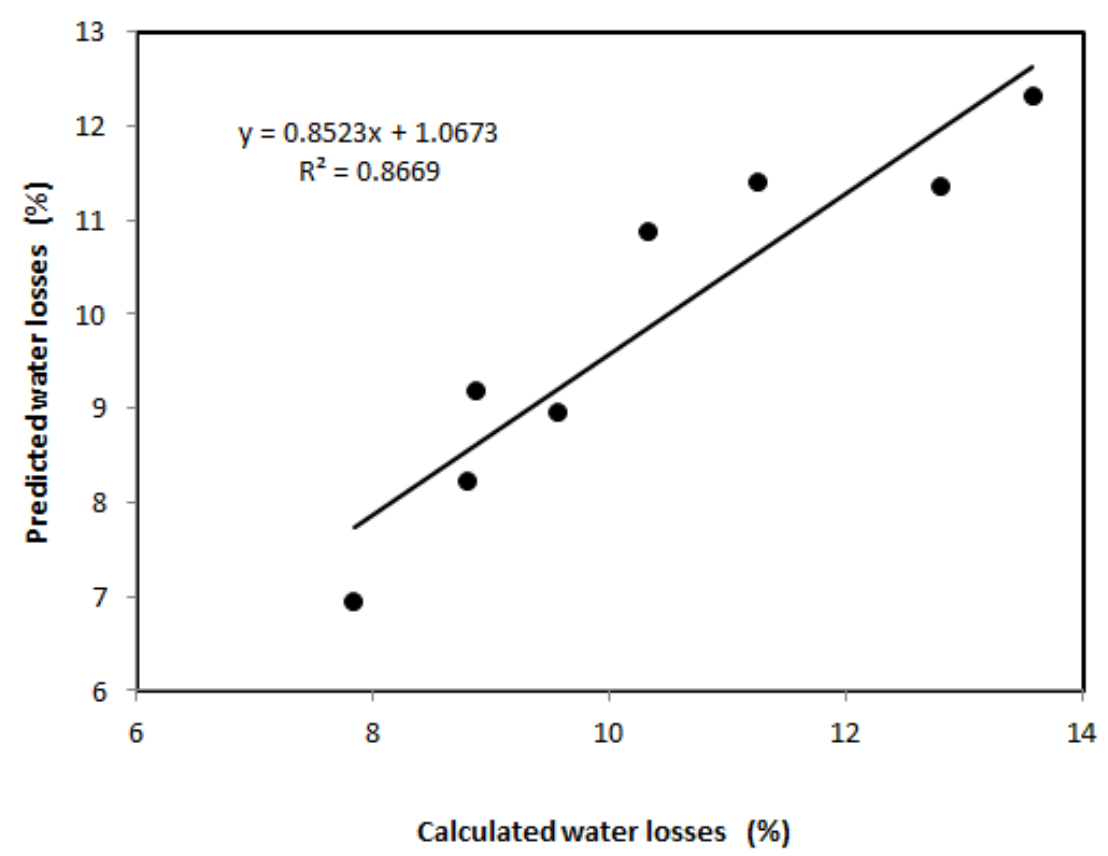

Fig. 6. Relationship between calculated and predicted water losses from center pivot systems in Riyadh region.

\section{CONCLUSION}

This study was conducted in Riyadh region, Saudi Arabia, to evaluate the performance of eight low pressure center pivot systems operated by the farmers under normal field condition. The evaluation of water distribution pattern along the 
lateral and water distribution uniformity of these center pivot systems showed that there were variations among the tested eight systems, and they generally performed poorly. The cause of non-uniformity was due primarily to meteorological and center pivot system parameters.

Also, the study was conducted to determine the water losses during irrigation under various climatic and operation conditions. The water losses are dependent upon both climatic and operating factors. The developed water losses model indicated that meteorological and center pivot system parameters have interactive effects on water losses during irrigation, and hence on the performance of center pivot systems. The results generated from this study are expected to draw the attention of the system designers and users to take into account the influence of climatic and operating factors on water uniformity and losses during irrigation under arid conditions. The developed model could provide valuable information for management of irrigation water losses under center pivot irrigation system. Further, managers of irrigation systems can use it to modify the available but the seasonal management practices to conserve limited water supply.

\section{REFERENCES}

1. Acar, B.; R. Topak, and M. Direk. 2010. Impacts of pressurized irrigation technologies on efficient water resources uses in semi-arid climate of Konya Basin of Turkey. Int. J. of Sustainable Water \& Environmental Systems, 1(1): $1-4$.

2. Al-Ghobari, H. M. 1992. Losses from low pressure center-pivot irrigation system in a desert climate as affected by nozzle height. Agriculture Water Management, 21: 23- 32.

3. Al-Ghobari, H. M. and F. S. Mohammed. 1995. Survey study about the crust problem in center pivot irrigation pipes in the Kingdom of Saudi Arabia. Agricultural Research Center; KSU 54 PP.

4. Al-Ghobari, H. M. 1996.The Effect of travel speed on spray losses from center pivot systems. J. King Saud Univ. Sci., 8: 111-123.

5. Al-Ghobari, H. M. 2014. Effect of center pivot system lateral configuration on water application uniformity in an arid area. J. of Agricultural Sciences and Technology, 16: $577-589$.

6. Allen, R. G.; J. Keller, and D. Martin. 2000. Center pivot system design. The Irrigation Association., www.irrigation.org. 
7. ASABE. 2007. ASABE Standard S436.1, test procedure for determining the uniformity of water distribution of center pivot and lateral move irrigation machines equipped with spray or sprinkler nozzles. American Society of Agricultural and Biological Engineers, St. Joseph, MI, USA.

8. Clemmens, A. J. and K. H. Solomon. 1997. Estimation of global irrigation distribution uniformity. J. Irrig. Drain. Eng., 123: 454- 461.

9. Dechmi, F.; E. Playan, J. Faci. and M. Tejero. 2003. Analysis of an irrigation district in northeastern Spain. I: Characterization and water use assessment. Agriculture Water Management, 61: 75-92.

10. Dukes, M. D. and C. Perry. 2006. Uniformity testing of variable-rate center pivot irrigation control systems. Precision Agriculture, 7: 205 - 218.

11. Evans, R. G. and B. A. King. 2012. Site-specific sprinkler irrigation in a waterlimited future. Trans. ASABE, 55: 493-504.

12. Hasanean, $\mathrm{H}$ and M. Almazroui. 2015. Rainfall: Features and variations over Saudi Arabia, A Review. Climate, 3: 578-626.

13. Harrison, K. and C. Perry. 2007. Evaluating and interpreting application uniformity of center pivot irrigation systems. Circular 911, University of Georgia, Athens, GA.

14. Heermann, D. F. and P. R. Hein. 1968. Performance characteristics of selfpropelled center pivot sprinkler irrigation systems. Trans. of the ASAE, 11: 1115.

15. Kincaid, D.C. 1986. Spray losses and uniformity with low pressure centre pivots. Paper No. 86-2091. Summer Meeting ASAE. California Polytechnic Institute. San Luis Obisp, CA.

16. Merriam, J. L. and J. Keller. 1978. Farm irrigation system evaluation: A Guide for Management. Utah State University, Logan, Utah.

17. Mohorjy, A. M. and N. S. Grigg. 1995. Water resources management system for Saudi Arabia. J. Water Resour. Plng. And mgmt., 121: 205-215.

18. Mun, S.; G.F. Sassenrath, A. M. Schmidt, N. Lee, M. C. Wadsworth, B. Rice, J.Q. Corbitt, J. M. Schneider, M. L. Tagert, J. Pote, and R. Prabhu. 2015. Uncertainty analysis of an irrigation scheduling model for water management in crop production. Agricultural Water Management, 155: 100-112. 
19. Ortiz, J. N.; J. A. de Juan, and J. M. Tarjuelo. 2010. Analysis of water application uniformity in a centre pivot and its effect on sugar beet (Beta vulgaris L.) yield. Biosyst Eng, 105:367-379.

20. Ring, L. and D. F. Heerman. 2001. Determining Center-pivot Sprinkler Uniformities: ASAE Paper No. 78. St. Joseph, MI 49085.

21. Rogers, D. H.; M. Alam, L. K. Shaw, and G. A. Clark. 2009. Impact of collector size and spacing on center pivot uniformity evaluations. ASABE Paper No. 096522. St. Joseph, Mich.

22. Sezen, S. M. and A. Yazar. 2006. Wheat yield response to line-source sprinkler irrigation in the arid southeast Anatolia region of Turkey. Agriculture Water Management, 81: 59-76.

23. Tarjuelo, J. M.; J. Montero, F. T. Honrubia, J. J. Ortiz, and J. F. Ortega. 1999. Analysis of uniformity of sprinkler irrigation in a semi-arid area. Agriculture Water Management, 40: 315 - 331. 


\title{
التقييم الحقلي لخصائص الأداء وفواقد المياه لنظم الري المحوري تحت ظروف المناخ الجاف
}

\author{
r، محمد سعيد عبدالله المرازقى
}

ا ـ معهد بحوث الهنسسة الزراعية، مركز البحوث الزراعية ، ص. ب ror ، الجيزة ، مصر.

r • قسم الهندسة الزراعية، كلبة علوم الأغذية والزراعة، جامعة الملك سعود، المملكة العربية

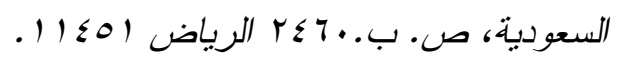

يعتبر نظام الري المحوري من أنسب نظم الري بالرش للمناطق الجافة أو شبه الجافة التي تتطلب قدرًا كبيرًا من مياه الري. ويستخدم نظام الري المحوري على نطاق واسع في المملكة العربية

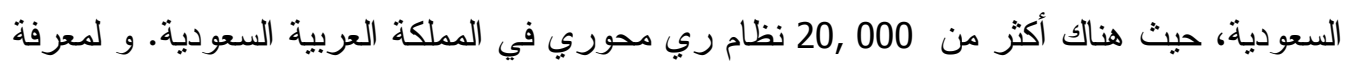

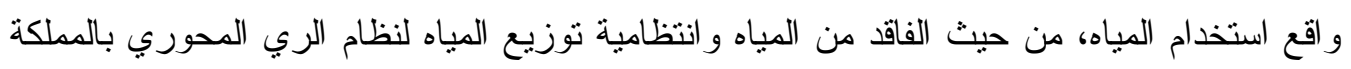

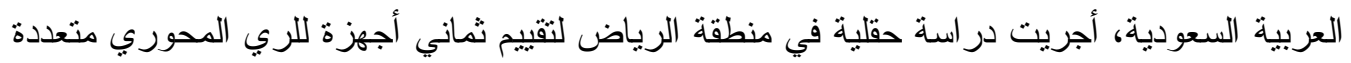
الأعمار وجهات التصنيع، وتتألف من عدد مختلف من الأبر اج تتراوح من 7 إلى 9. أن معظم نظم الري المحوري أعطت قيم منخفضة لانتظامية توزيع المياه علي طول خط الرش

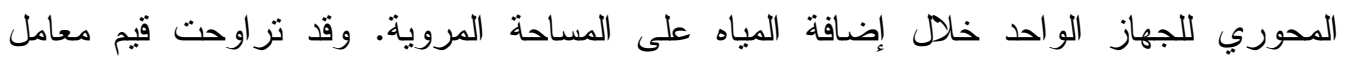

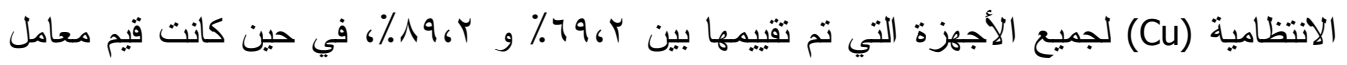

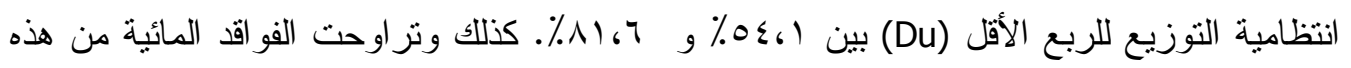

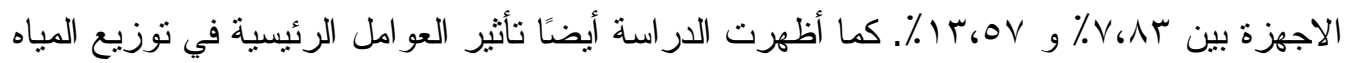
و الفاقد منها في منطقة الرياض من خلال نطوير نموذج رياضي لتحديد العلاقة بين فو اقد المياه و العو امل المؤثرة فيها تحت ظروف التشغيل الحقلية. وتقيد نتائج الدر اسة المز ارعين لتحديد المشاكل وكيفية تحسين أداء النظام، وبالتالي فإن النموذج الرياضي المطور يمكن أن يوفر معلومات قيمة عن فئن استخدام و فو اقد مياه الري مع نظام الري المحوري في المنطقة التي نو اجه الجفاف وندرة المياه. 